\title{
The State of Markets for Technology in Chile
}

\author{
Goretti Cabaleiro ${ }^{1^{*}}$, Felipe Salce ${ }^{1}$
}

\begin{abstract}
The purpose of this paper is twofold. First, we show the importance of having a developed Market for Technology and how innovation affects countries' economic development. Second, using the main innovative indicators, we describe the current Market for Technology in Chile and discuss its possible impact on the country's economic development.
\end{abstract}

Keywords: R\&D expenditure; Patent licensing; Markets for Technology; Intellectual Property Rights; Chile

Submitted: August 30 $30^{\text {th }}, 2017$ / Approved: April $3^{\text {rd }}, 2018$

\section{Introduction}

Innovation management has proven to be an important factor in economic development in the last few decades, and its importance is expected to increase exponentially in the era of Artificial Intelligence (IA) and Automatization. Therefore, governments and companies have attempted not only to improve the knowledge and understanding of present innovative output processes, but also to determine how to adapt them better for the future. In particular, recent studies show that IA will change our lives significantly: $51 \%$ of the jobs will be automated in 2030; $15 \%$ of the new sold cars in 2030 will be fully automated; and cities will become intelligent, and our future everyday lives will be different due to the predominance of the Internet of Things (IoT) (Mckinsey \& Company, 2016).

In this context, characterized by increasing competition in the product market, shorter product life cycles and very fast development of IA, companies cannot produce everything by themselves. As a consequence, new ways to manage innovation have emerged, but not all countries seem to be conscious of the importance of this change and its implications. In particular, companies have switched from innovating only through internal $\mathrm{R} \& \mathrm{D}$ to buying and selling technology and know-how in Markets for Technology (MFT). To be efficient and competitive, companies have increasingly begun to rely on networks, new entrants and technology-based firms. These new relationships mean that, each year, MFT become more and more important for countries' economic development.

Although the US and Europe have produced studies to quantify the importance of MFT (Arora et al., 2001; Athreye \& Godley, 2007; Robbins, 2009) and their main determinants (Arora \& Fosfuri, 2003; Gambardella et al. 2007; Zuniga \& Guellec, 2009; De Leon et al., 2017), there are still no such studies for Chile. We believe that the main reason for this lack of studies is Chile's traditional deficit regarding innovation and, as a result, the absence of comprehensive indicators to measure innovation processes. Therefore, we consider that there are two things that are highly needed for Chile. The first is to create awareness about the impact that innovation has on most important economic variables; and the second is to demonstrate the low level of development of Chile's Markets for Technology or, at least, the absence of indicators that might demonstrate the opposite.

The rest of the paper is organized as follows. Section 2 will review the literature that relates innovation with the main economic variables and the theory regarding MFT. Section 3 will summarize the situation in Chile regarding the main innovative indicators. We conclude in Section 4 .

\section{The importance of Innovation and the development of Markets for Technology (MFT)}

The literature has shown that innovation is positively correlated with countries' economic development and total productivity (Hall \& Rosenberg, 2010). Since Adam Smith, in the $18^{\text {th }}$ century, economists have been interested in the role that innovation plays in economic development (Agrawal, 2001). In that vein, Solow (1957) and Fagerberg (1994) conclude that innovation is a key contributor to economic progress. Romer (1990) shows that technology, the development of human capital, and R\&D are important inputs for economic growth. On the empirical side, $\mathrm{Wu}$ (2011), using data from China, finds that $\mathrm{R} \& \mathrm{D}$ intensity has a positive effect on innovation and, in turn, that innovation affects a country's economic growth positively. Pradhan et al. (2016), using panel data from the euro zone between 1961 and 2003, provide results along the same lines. Furthermore, Rouvinen (2002), using data from the OCDE, concludes that R\&D expenditures take, on average, four years to influence economic growth, and he shows causality between R\&D investment and the TFP and not in the other way around.

In studies related to productivity, Griliches (1987) shows that R\&D activities can explain $75 \%$ of productivity growth rates. Benavente (2006), Alvarez et al. (2010) and Crepon et al. (1998) show that R\&D expenditures are positively related to firm size, market share and diversification, and they find a positive correlation between productivity and higher innovation performance. In a similar study for Italy, Parisi et al. (2006) demonstrate that the innovation process has a positive impact on productivity and that R\&D expenditures are strongly and positively related to the likelihood of introducing

(1) Faculty of Business and Economics, Universidad Alberto Hurtado

*Corresponding author: gcabaleiro@uahurtado.cl 
new products in the market. Thus, they conclude that R\&D affects productivity growth because it facilitates the understanding of new technologies.

Therefore, based on previous results, there appears to be a consensus regarding the positive impact of innovation on economic progress and productivity. Since managers know the crucial role of innovative technology knowledge in firm performance and economic growth, they have put much effort into protecting it. In fact, according to OROPO (2015), in June 2015, there were approximately 20 million patents in the world. However, patenting does not imply receiving benefits from the innovation since companies do not use the most of their patents. For instance, a survey made by the Japan Patent Office shows that more than $60 \%$ of Japanese patents are not used at all, while $30 \%$ are used internally and almost the $10 \%$ are licensed (JPO, 2004). Given the great number of unused patents and the cost that that implies, companies have shift to a more open model of innovation, whereby they can buy the technology that they need to push forward the innovative process, or they can sell the patented technology to benefit from it somehow. In that sense, licensing agreements have become an important way to transfer technology. In particular, licensing consists of an agreement between the patent holder (licensor) and the other party (licensee), through which the licensor allows the licensee to make, sell and use the patent without transferring its ownership through the Markets for Technology (MFT) ${ }^{1}$ (Granstrand et al., 1997). Due to technological convergence, increasing interdependence of different technologies, and the resulting need to rely on diverse technological components for downstream products and services MFT has dramatically expanded in the last two decades providing access to third- party technologies.

Several studies have noticed the increasing trend toward MFT and have quantified their extension during the last two decades. In particular, Arora and Gambardella (2001) estimate that in the mid-1990s, the annual value of transactions in the market for technology was \$25-35 billion in the United States and about \$35-50 billion globally. Robbins (2009) estimates the size of the 1997 worldwide technology market at about $\$ 31.8$ billion. Athreye and Cantwell (2005) quantify the 2000 world technology market at $\$ 90-100$ billion. A survey by the British Technology Group (2006) estimates the size of the market for technology to be $\$ 25$ billion in North America, $\$ 6.6$ billion in Europe and $\$ 8.3$ billion in Japan. Therefore, at the aggregate level, markets for technology have grown significantly over the last decades, and they appear to be most developed in the United States, followed by Japan and then Europe. There is no such study for Chile.

The development of MFT is important for a country because they allow the diffusion of innovative knowledge and, thus, offer opportunities to innovate beyond internal R\&D and, in turn, to develop economically. If we follow economic theory, $\mathrm{R} \& \mathrm{D}$ has a positive effect on the growth of sales and, in turn, on the growth of companies
(García-Manjón \& Romero-Merino, 2012). However, sometimes investing in internal $\mathrm{R} \& \mathrm{D}$ and patent protection is time-consuming, companies could not have the necessary inventory capacities (e.g. human capital or infrastructure), the financial resources for developing the product, or the legal capacities to settle patent infringement lawsuits in court. Moreover, maintaining patents over time implies a cost and, depending on the use that a company makes of the patent, the cost may be worth it or not. In this sense, licensing-in can facilitate the process. In general terms, licensing agreements are positive for society since they provide strategic advantages for licensors and licensees. On the demand side, licensees can benefit from acquiring externally developed and proven technologies (Atuahene-Gima, 1993); from reducing the risks and costs related to product development (Lowe \& Taylor, 1999); and from adopting more diversified and less integrated R\&D structures (Chesbrough, 2003). On the supply side, licensors increase the possibilities of recovering the investments and generating revenue from innovations (Arora \& Ceccagnolli, 2006; Teece, 1986); achieving rapid market penetration (Lei \& Slocum, 1991); and facilitating the development of complementary products (Shepard, 1987). Given its advantages, licensing has become the most important option to transfer technology (Anand \& Khanna, 2000; Arora \& Fosfuri, 2003). In fact, given its significance, the U.S. Department of Justice has defined markets for technology as "markets that consist of intellectual property that is licensed and its close substitutes" (U.S. Department of Justice, 1995).

Despite the growth in their use, licensing agreements are still confidential in most countries, and it is not compulsory for companies to report them as a separate item on their income statements. As a consequence, innovation at the country level is still measured using $R \& D$ expenditures or the number of patents granted in a given year, regardless of whether the patents are used and without knowing what company is using this knowledge. These practices make it difficult to measure the effect of innovation on a country's economic development and productivity rate.

\section{Literature Review: MFT in Chile}

\subsection{Actual economic situation in Chile}

Although Chile has sustained economic growth over time, in the last decades, that growth has accelerated, with a primary focus on the extraction of natural resources, mainly mining (De Gregorio, 2009). However, nowadays, the Chilean economy is facing a deep slowdown in terms of GDP per capita. Using data from the Central Bank, Figure 1 shows that between 1980 and 2011, Chile's per capita GDP increased steadily. However, over time, the increases became smaller, so in economic terms, the Chilean economy was actually slowing down. Moreover, we observe that economic growth was lower than $3 \%$ in the last three years and that the Central Bank's projections indicate that the rate will not exceed $4 \%$ in the next five years.

(1) Markets for technology refer to transactions for the use, diffusion and creation of Intellectual Property Rights (IPR). 
Figure 1: GDP per capita PPP (USD, FMI) and growth rate.

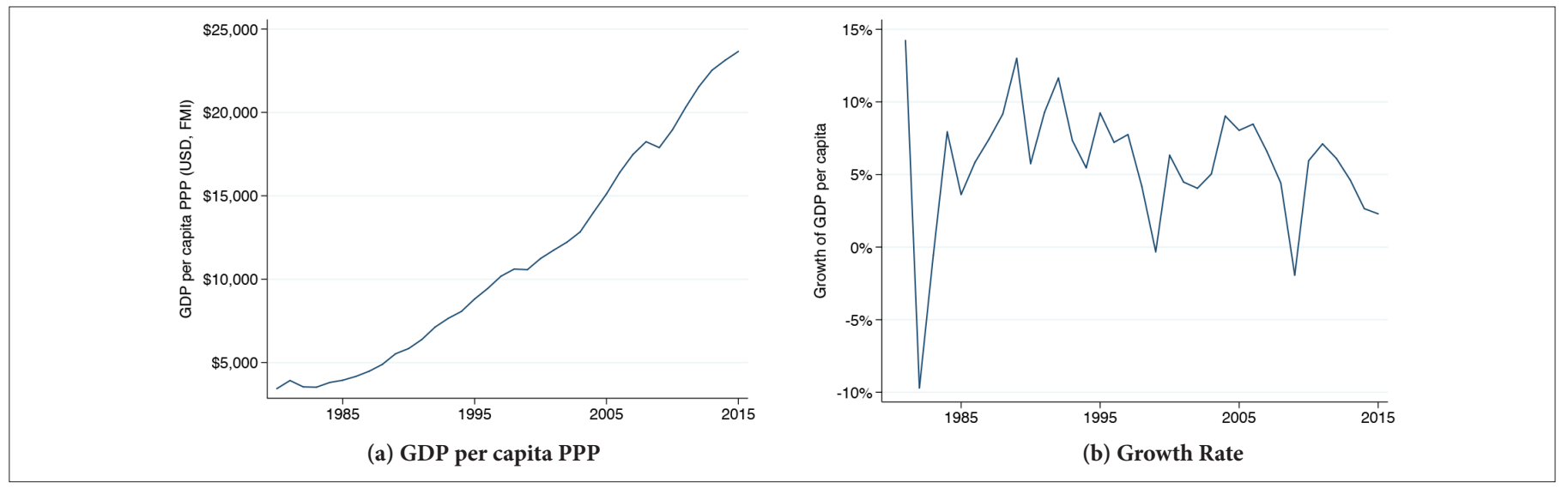

Source: Own elaboration based on data from the Central Bank of Chile.

In terms of productivity, Bravo-Ortega et al. (2014) find that Chilean companies that invest more in $\mathrm{R} \& \mathrm{D}$ are more likely to become export companies and that R\&D spending affects productivity in two different ways: (i) directly and (ii) indirectly through exports. Using data from the World Bank and Fernández-Arias (2014) for IADB, we estimate the relationship between productivity and expenditures in R\&D as a percentage of the GDP of different countries between 1986 and 2011. Figure 2 shows the low average productivity of Chilean companies. These results are consistent with those obtained by Benavente (2004) for the period between 1985 and 2000. In particular, we observe the comparison of both estimates in Table 1, where Model 1 corresponds to the model estimated by Benavente (2004) and Model 2 to the one that we estimated. Finally, the econometric model can be observed in Equation 1.

$$
\ln (T F P)=\alpha+\beta \cdot \frac{R \& D}{G D P}
$$

Figure 2: Relationship Between Productivity and R\&D Expenditure (1996 - 2011)

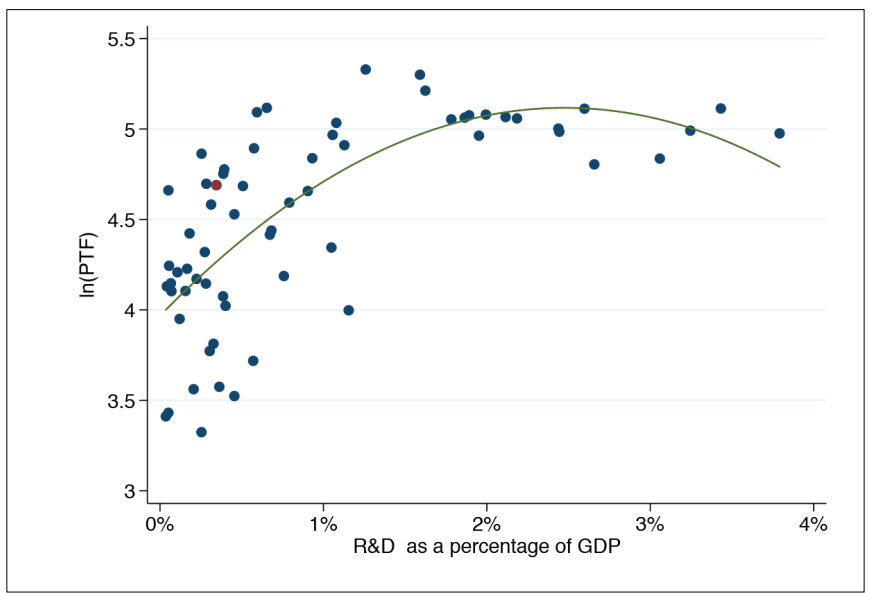

Note: Natural Logarithm of the TFP constructed as the average of the natural logarithm of the TFP per year, between 1996 and 2011; data obtained from Fernández-Arias (2014). R\&D constructed as the average of R\&D as a percentage of GDP between 1996 and 2011, for the countries and periods for which there was information in the World Bank database.

Source: Authors' own elaboration based on data from the World Bank and Fernández-Arias (2014).
Table 1: Results

\begin{tabular}{lccc} 
& $\alpha$ & $\beta$ & $R^{2}$ \\
\hline Model 1 & 5,8 & 0,2 & 0,4 \\
Model 2 & 4,2 & 0,3 & 0,4 \\
\hline \hline
\end{tabular}

Source: Authors' own elaboration based on Benavente (2004) and data from the World Bank and Fernández-Arias (2014).

Using data from Fernández-Arias (2014), we can observe the productivity of Chile and of other Latin American countries since 1960. Chile's productivity decreased by $21 \%$ between 1960 and 2011 and by $0.6 \%$ since 2000. If we compare Chile with Latin America, we observe that Chile's productivity has surpassed the Latin American average since the 1980s, as shown in Figure 3.

Figure 3: TFP Chile and Latin America (1960 - 2011)

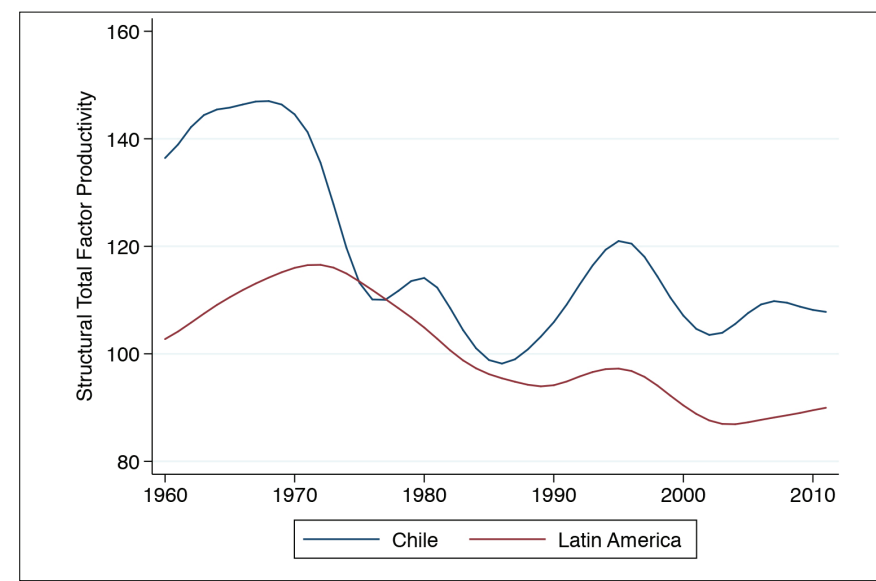

Source: Authors' own elaboration based on data from Fernández-Arias (2014).

Furthermore, using the same data from Fernández-Arias (2014), we can observe Chile's productivity as a percentage of the United States'. In Figure 4, we compare it with the average productivity in Latin America (including Chile), the rest of the world, and East Asia as a percentage of the United States' productivity. It is easy to observe that, in all cases, there has been a large drop in productivity in relation to the United States, with Latin America the most affected. Chile is currently well above the average for the region and the world average, but below that of East Asia. 
Figure 4: TFP Chile, Latin America, East Asia and Rest of the World as Percentage of United States TFP (1960 - 2011).

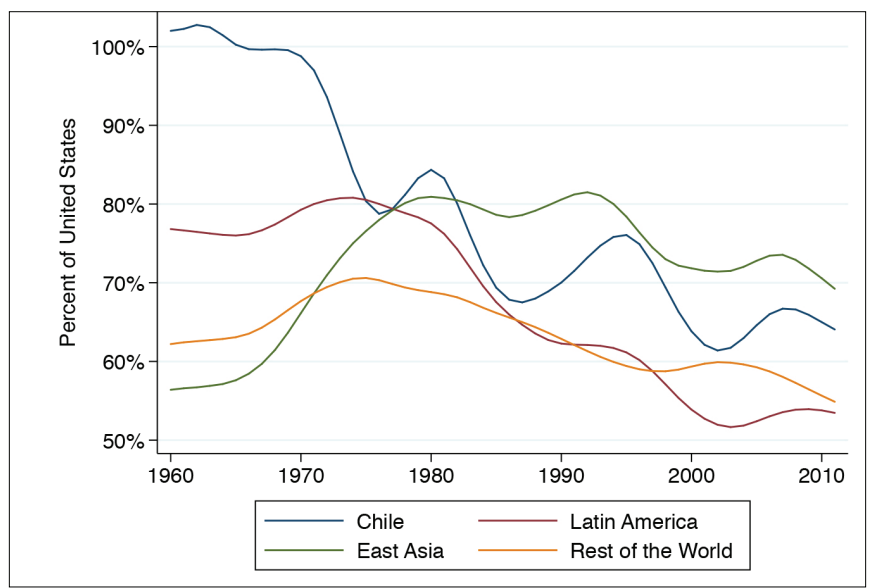

Source: Authors' own elaboration based on data from Fernández-Arias (2014).
Finally, Corbo and Gonzalez (2014) estimate the contribution of TFP to GDP growth in Chile in the last 30 years using data from the Central Bank and the Instituto Nacional de Estadísticas (INE) of Chile (Table 2). It can be seen that the contribution is negative in the last fifteen years, after having had good productivity in the 1990s.

Table 2: Sources of Growth 1987-2011

\begin{tabular}{ccccccc} 
GDP Growth & $\begin{array}{c}\text { Contribution of } \\
\text { Non-ICT Capital } \\
\text { Services } \\
(2)\end{array}$ & $\begin{array}{c}\text { Contribution of } \\
\text { ICT Capital } \\
\text { Services } \\
(1)\end{array}$ & $\begin{array}{c}\text { Contribution of } \\
\text { Total Capital } \\
\text { Services } \\
(4)=(2)+(3)\end{array}$ & $\begin{array}{c}\text { Contribution of } \\
\text { Labor Services }\end{array}$ & $\begin{array}{c}\text { Contribution of } \\
\text { TFP Growth }\end{array}$ \\
\hline $1987-2012$ & $5,5 \%$ & $2,3 \%$ & $0,9 \%$ & $3,2 \%$ & $1,9 \%$ & $(5)$ \\
$1987-1991$ & $7,0 \%$ & $1,8 \%$ & $0,5 \%$ & $2,3 \%$ & $2,8 \%$ & $1,4 \%$ \\
$1992-1997$ & $7,6 \%$ & $2,9 \%$ & $0,9 \%$ & $3,8 \%$ & $1,8 \%$ & $2,0 \%$ \\
$1998-2003$ & $3,1 \%$ & $2,0 \%$ & $0,7 \%$ & $2,7 \%$ & $1,4 \%$ & $-1,0 \%$ \\
$2004-2008$ & $5,5 \%$ & $2,2 \%$ & $1,6 \%$ & $3,8 \%$ & $1,9 \%$ & $-0,2 \%$ \\
$2009-2012$ & $4,0 \%$ & $2,4 \%$ & $0,5 \%$ & $2,9 \%$ & $1,9 \%$ & $-0,8 \%$ \\
\hline
\end{tabular}

Source: Corbo and Gonzalez (2014)

Regarding the relationship between innovation and employment, Benavente and Lauterbach (2008) using data from 1998 to 2001, show that product innovation positively influences employment in Chile. Also, Alvarez et al. (2011a), using data from Chilean companies, conclude that product innovation could be positively related to an increase in employment, independent of the size of the firm. Furthermore, they analyze the relationship between innovation and employment and find that $\mathrm{R} \& \mathrm{D}$ internal expenditures positively affect employment for both qualified and non-qualified workers. Moreover, Zuniga and Crespi (2013) analyze the impact of innovation strategies on the increase in employment in three countries: Argentina, Chile and Uruguay. In particular, they distinguish three different strategies: internal R\&D only; only buying R\&D (licensing in patents or know how, etc.); and internal R\&D and buying R\&D simultaneously. They find that companies with only internal R\&D have a greater and significative positive effect on the employment rate, followed by companies that implement a mixed strategy (internal $\mathrm{R} \& \mathrm{D}$ and buying R\&D). In particular, Figure 5 shows the unemployment rate in Chile in the last thirty years, with data from the Central Bank of Chile. Even though the unemployment in Chile seems to be quite volatile, it is important to note that the variations correspond to small percentage changes, with a slight downward trend in the last thirty years. Moreover, unemployment has remained between 5.5\% and 7.5\% over the last five years.
Figure 5: Unemployment Rate in Chile (1985-2017)

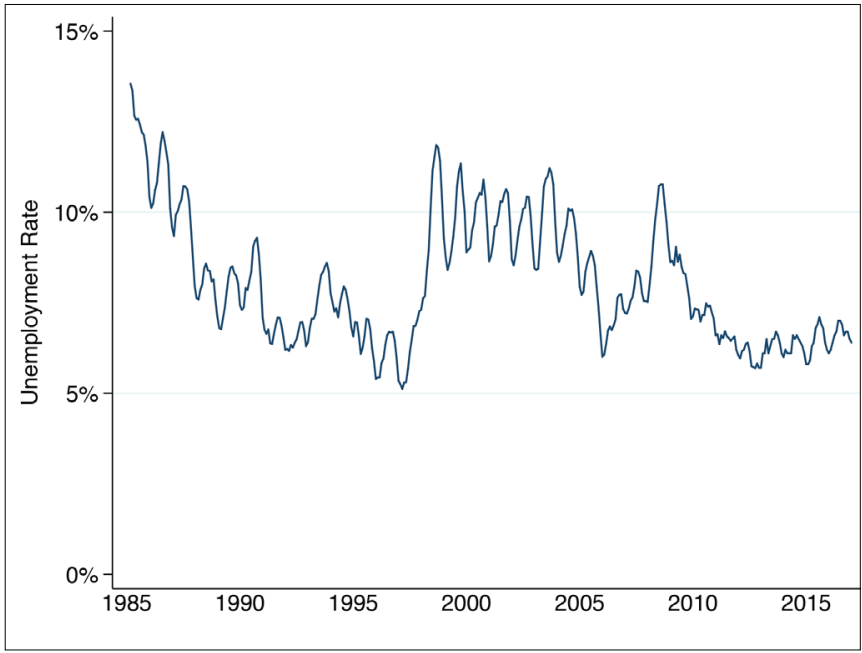

Source: Authors' own elaboration based on data from the Central Bank of Chile.

\subsection{Actual situation in Chile regarding the development of MFT}

In the last three decades, innovation management has become a very important part of the agenda in developed countries. Governments and companies have put great effort into acquiring the knowledge and un- 
derstanding to complement the existing indicators of innovation process outputs. Indeed, it is important to know not only the input needed to innovate- $R \& D$ expenditures - but also the output of the innovative process. For this purpose, the most common indicators at the country level are: (i) the number of annual patent applications; (ii) annual patent grants; (iii) annual licensing agreements; (iv) active patents and licenses (portfolio); and (v) annual licensing revenues (Abud et al., 2013). The above five indicators will help us to understand the entire innovation process since the input represented by the R\&D expenditures to their economic implication represented by revenues.

Regarding the innovative input measures at the country level, R\&D expenditures in Chile are low. In fact, Alvarez et al. (2011b) state that analyzing Chile is interesting because of its delayed development relative to the rest of the developing countries in terms of initiatives and policies to innovate: Chile's R\&D expenditures represent just the $0.68 \%$ of GDP, a percentage that represents less than $40 \%$ of the OECD average and that situates Chile just ahead of Mexico, Argentina, Poland and Turkey (OECD, 2007). In the same vein, Maloney and Rodríguez-Clare (2007) offer evidence that Chile suffers from an R\&D investment deficit. In particular, Figure 6 shows the level of $\mathrm{R} \& \mathrm{D}$ in OECD member countries, divided into public and private investment in 2001. In that figure, we see that R\&D investment in Chile is half the OECD average. Given this, experts assert that, given the per capita income level of the country, R\&D investment in Chile should be much higher (Alvarez et al., 2011b). Following the same path, Cruz (2008) argues that although Chile present a low level of innovation, the country has been advanced slowly. Finally, Canales \& Álvarez (2017) show that there are obstacles, such as financial restrictions and the low availability of human resources and information on markets and new technologies, that reduce the likelihood of innovation of Chilean companies.

Figure 6: R\&D intensity as a Percentage of GDP (2001)

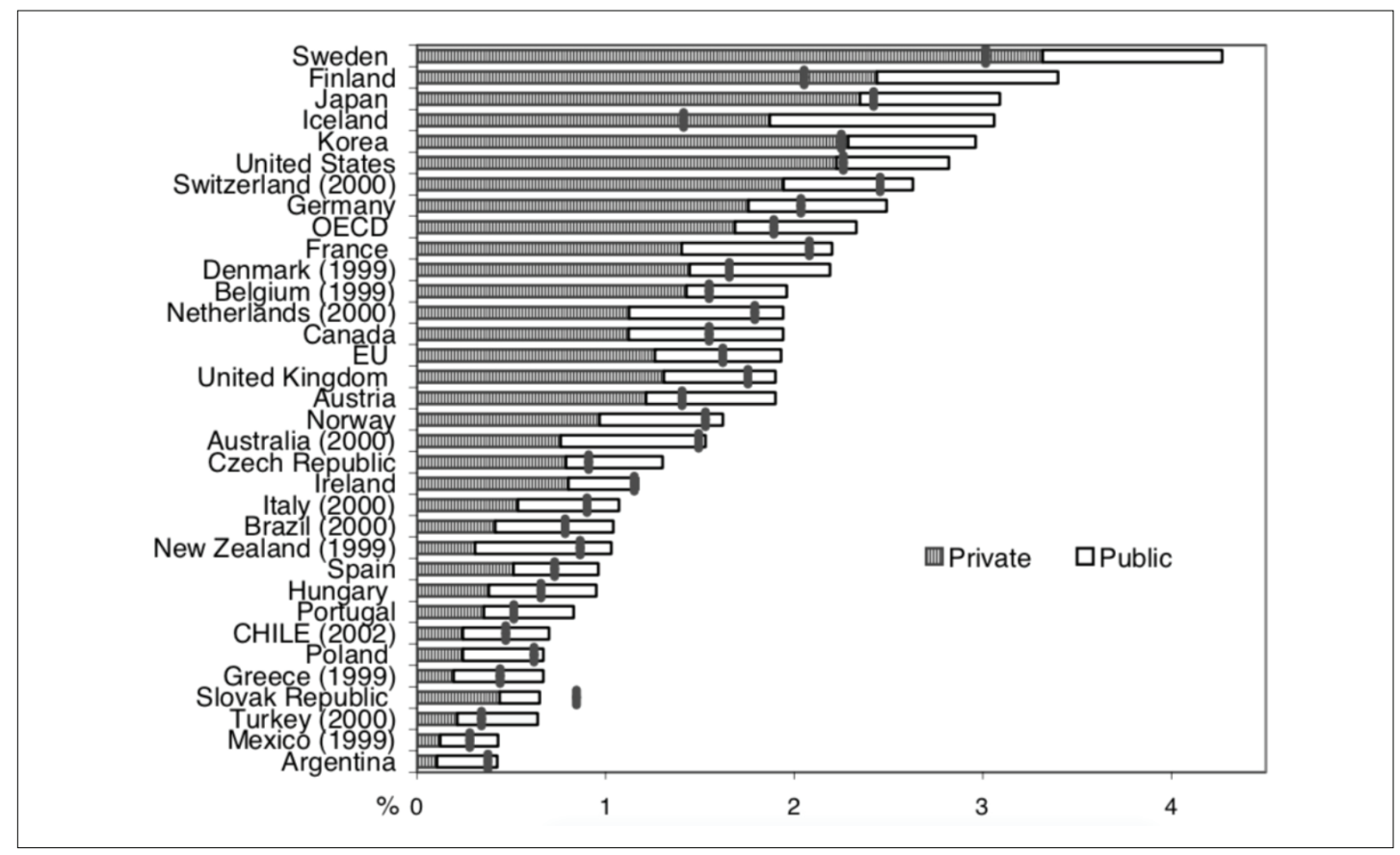

Source: Benavente et al. (2005)

Regarding the output measures, Chile does not provide comprehensive or comparable information for all of them. Regarding the first and the second measures - the number of annual patent applications and the annual patent grants-information is available from the National Institute of Intellectual Property (INAPI). The number of annual patent applications tripled in the period from 1991 to 2010; in 2009 and 2010, they showed a dramatic decrease, and, after recovering, they have decreased slightly again in the last two years. In addition, the number of resident patent applications grew very slowly over time, averaging 290 applications per year between 1990 and 2017 (Figure 7$)$. In general terms, more than $90 \%$ of the applications are from non-residents in the country, generally from the US and Europe, and most of the requests come from multinational pharmaceutical firms and chemical companies (around 60\%). This scenario differs from that in developed countries. In Figure 8, we observe a breakdown of the applications for patents, industrial designs, utility models and trademarks. Here, we see that most of the patent and industrial design applications come from non-residents, while most of the applications for trademarks and utility models are initiated by residents. Figure 9 shows patents by sector and by the resident vs non-resident classification. Most of the patent (both resident and non-resident) belong to the chemical and mechanical engineering sectors. 
Figure 7: Evolution of Patents Applications in Chile

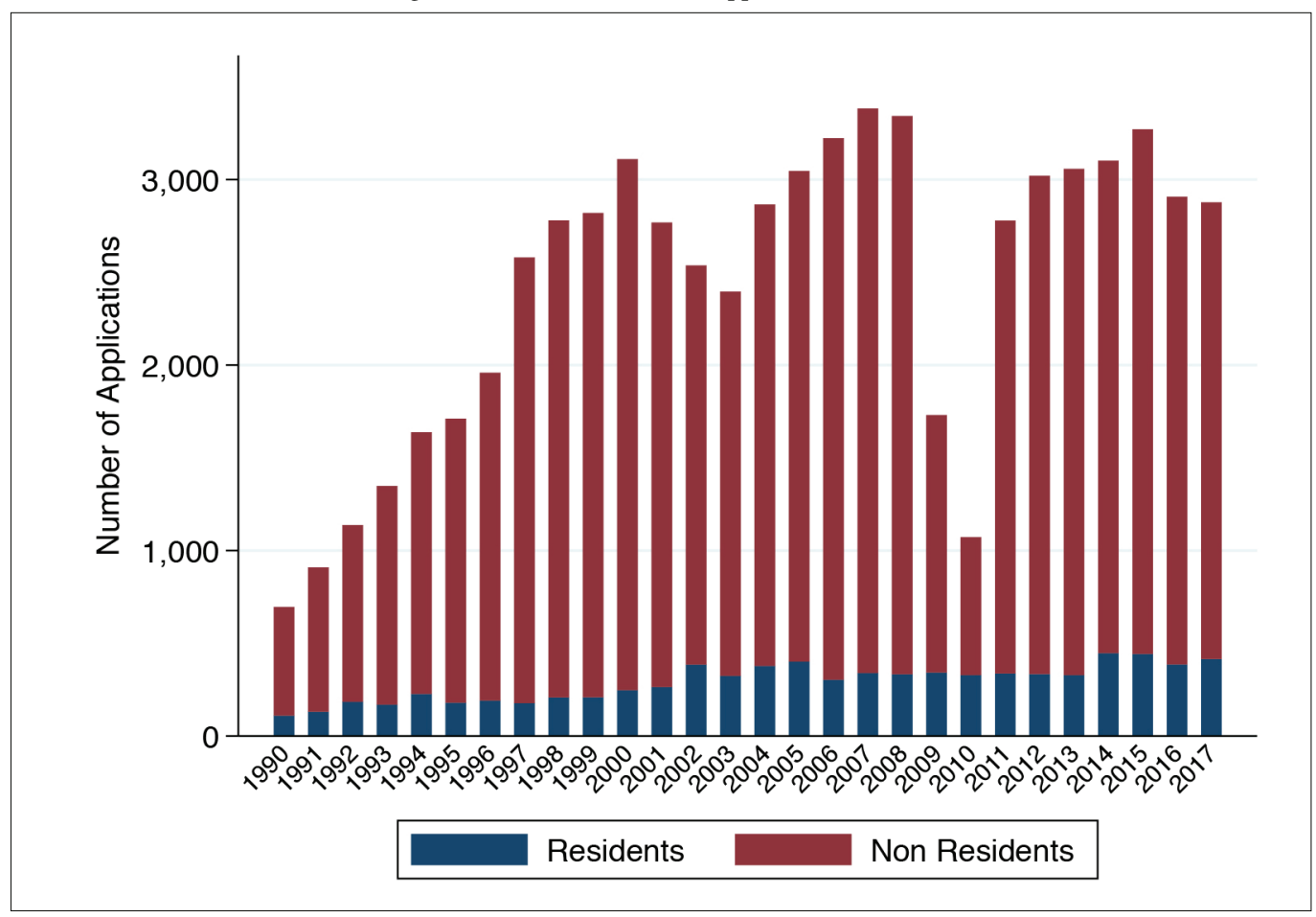

Source: Authors' own elaboration based on data from National Institute of Intellectual Property (INAPI), Ministry of Economy, Development and Tourism of Chile

Figure 8: Evolution of Patents Applications, Utility Models, Designs and Trademarks in Chile: Resident vs Non Resident

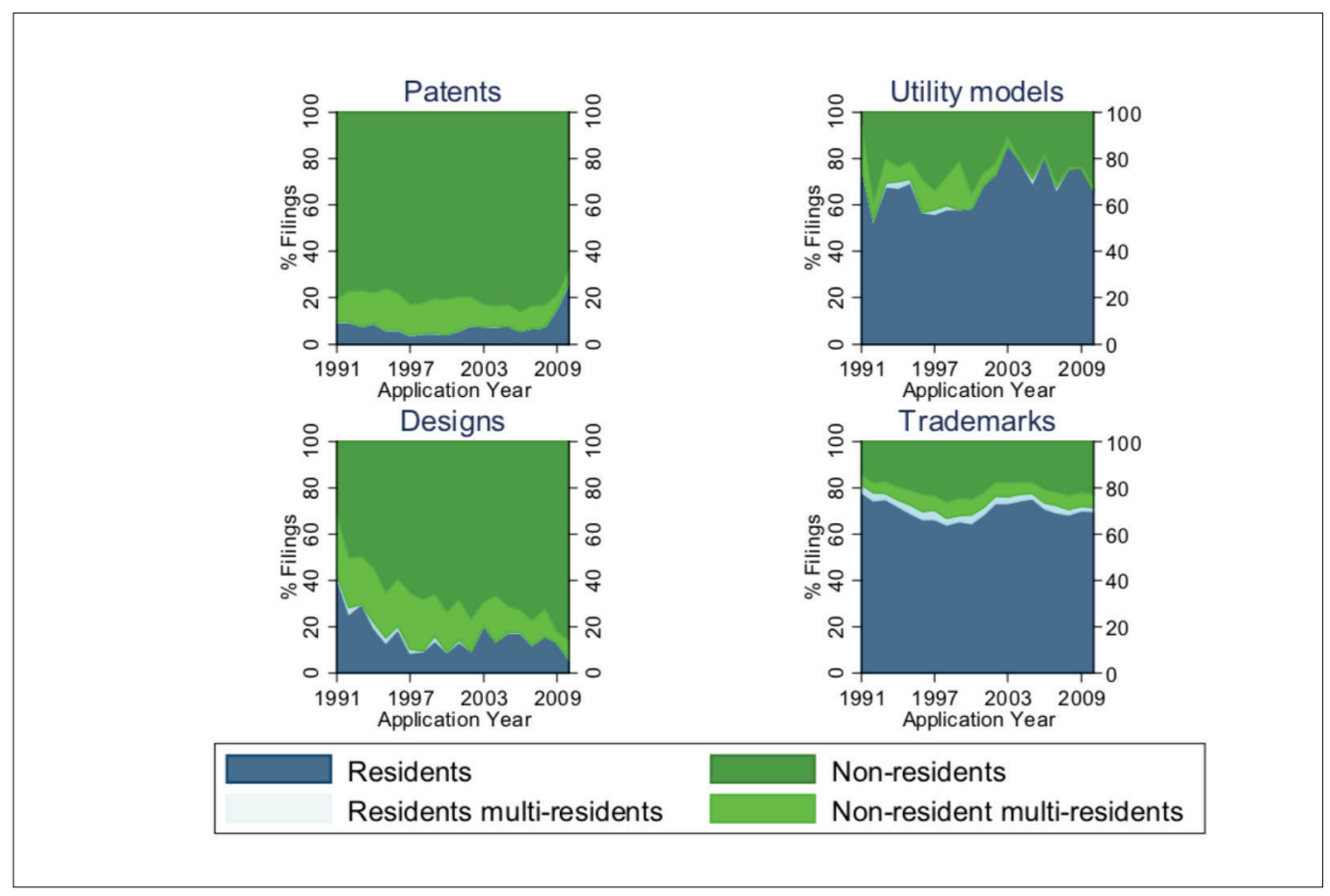

Source: Abud et al. (2013) 
Figure 9: Patents Applications by sector: Resident vs Non Resident.

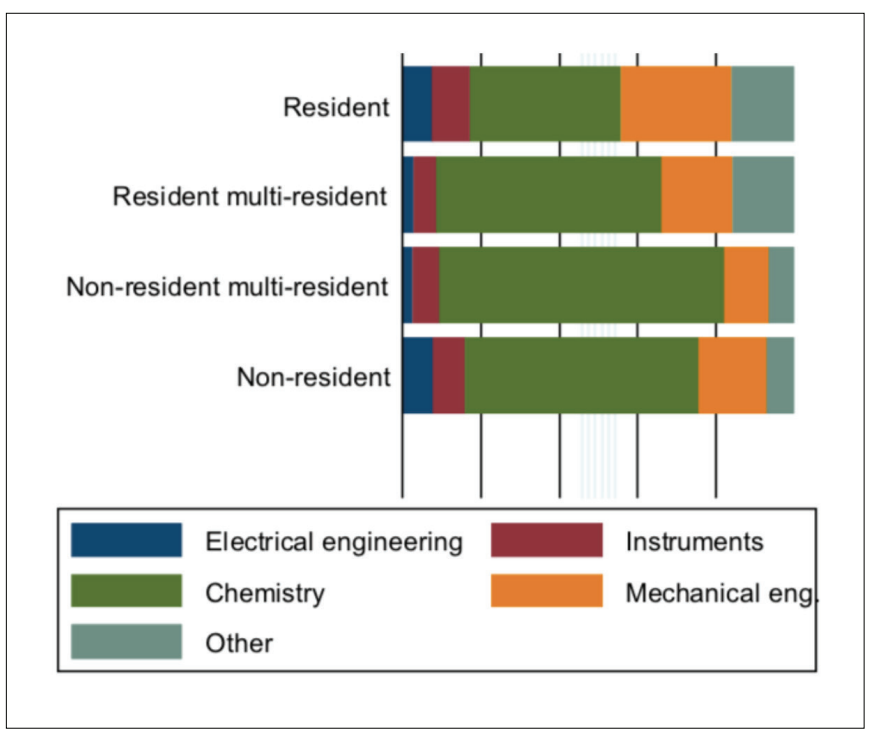

Source: Abud et al. (2013)

Regarding annual licensing agreements, in Chile, there is the option for residents and foreigners to register every licensing agreement with the National Institute of Intellectual Property (INAPI). Registering the agreement provides the parties involved with some advantages if they have legal problems with a third party. The records consists of simple statements in which the parties and the subject matter are reported, without disclosing the total content of the contract or the price of the transaction. In 2016, only $7 \%$ of the total marginal registration requests received by Inapi corresponded to licenses. Despite this low number, evidence has shown that more established licensing agreements exist in Chile than just the ones registered. In particular, Reyes and Teresa, in a thesis published in 2008, ran a survey of the patents holders, asking them if they have licensed the technology. They found that while, in 2007, there were just 14 licensing agreements registered, 60 patents holders responded that they had licensed their technology. This method of giving only general information regarding these contracts is common even in countries in which Markets for Technology are more developed.

Regarding the active number of patents and licenses, there is no official site where one can find this information. To the best of our knowledge, Reyes and Ripamonti (2008) use only an approximate number. Through their survey of patent holders, they estimate that the percentage of patents used in Chile are between the $58 \%$ and the $78 \%$ of the total patents and that the percentage of patents licensed is between $8 \%$ and $24 \%$. Both estimates are within the same range as in developed countries.

Regarding the last indicator, annual licensing revenues, no study has tried to estimate this amount. This is due to the low number of licenses registered with the INAPI and the lack of interest in making the economic terms of these contracts public.

\section{Conclusions}

Researchers have always been interested on the relationship between innovation and the main economic indicators. Although it seems that there is a consensus regarding the positive effect of innovation on economic development, productivity and employment, it is quite difficult to analyze the relationship because innovation is measured by using only an input measure: $\mathrm{R} \& \mathrm{D}$ expenditures. In this paper, we summarize output indicators to proxy innovation, and we analyze them in the context of Chile to understand how MFT are developed there. Regarding the input measure, we show that Chile has always presented a deficient amount of $R \& D$ expenditures. In fact, Chile $\mathrm{R} \& \mathrm{D}$ expenditures are half the average of the OCDE countries'. Regarding the output measures, Chile does not provide comprehensive or comparable information for all of them. In particular, we found information only on the number of annual patent applications and annual patent grants, available from INAPI, and these indicators are not very promising. In fact, most of the patent applications and patent grants have been initiated by non-residents. Regarding the annual licensing agreements, the active number of patents and licenses, and the annual licensing revenues, Chile has no official indicators and no official way to record these data. Therefore, we conclude that the Markets for Technology in Chile are not developed: we could find no indicators to prove otherwise, and the scarce official information available shows a serious national innovation deficit.

However, given the fast development of IA and the automatization era, as well as all the interesting challenges that are facing our societies, companies will need to manage innovation in an effective way in order to remain competitive in the product market. Even the more traditional companies will be forced to switch from innovating strictly through internal R\&D to adopting an open approach that allows them to buy and sell technology in the Markets for Technology.

The extent of the Markets for Technology has dramatically increased in developed countries over the last decades, thus facilitating the diffusion of technological knowledge. Since licensing has been the most demanded option for transferring technology, most of the studies that quantify the development of MFT have focused on the aggregate quantity of royalties and fixed fees charged in the market. Therefore, Chile should consider ways to record the data needed to facilitate research and, of course, the diffusion of the innovative knowledge that will be necessary to remain competitive.

\section{References}

Abud, M.J., Fink, C., Hall, B., \& Helmers, C. (2013). The Use of Intellectual Property in Chile. Economic Research Working paper 11

Anand, B.N., \& Khanna, T. (2000). Do Firms Learn to Create Value? The Case of Alliances. Strategic Management Journal. 21(3), 295-315. https://doi.org/10.1002/(SICI)1097-0266(200003)21:3<295::AIDSMJ91>3.0.CO;2-O 
Agrawal, A. (2001). Innovation \& Growth: Implications for Canada. Innovation Analysis Bulletin 4(3), 3-6.

Alonso-Borrego, C., \& Collado, D. (2002). Innovation and Job Creation and Destruction: Evidence from Spain. Rech. Économiques Louvain 68(1), 148. https://doi.org/10.3917/rel.681.0148

Alvarez, R., Benavente, J.M., Campusano, R., \& Cuevas, C. (2011a). Employment generation, firm size, and innovation in Chile. InterAmerican Development Bank, IDB-TN-319

Alvarez, R., Bravo-Ortega, C., \& Navarro, L. (2011b). Innovación, Investigación y Desarrollo y Productividad en Chile. Revista CEPAL, 104, 141-166.

Alvarez, R., Bravo-Ortega, C., \& Navarro, L. (2010). Innovation, R\&D Investment and Productivity in Chile. SSRN Electronic Journal. doi: $10.2139 /$ ssrn. 1818741

Arora, A., \& Ceccagnoli, M. (2006). Patent Protection, Complementary Assets, and Firms' Incentives for Technology Licensing. Management Science, 52(2), 293-308.

doi:10.1287/mnsc.1050.0437

Arora, A., Fosfuri, A., \& Gambardella, A. (2001). Markets for Technology and their Implications for Corporate Strategy. Industrial and Corporate Change, 10(2), 419-451. https://doi.org/10.1093/icc/10.2.419

Arora, A., \& Fosfuri, A. (2003). Licensing the market for technology. Journal of Economic Behavior \& Organization, 52(2), 277-295. doi:10.1016/s0167-2681(03)00002-7

Arora, A., \& Gambardella, A. (2010). Ideas for rent: an overview of markets for technology. Industrial and Corporate Change, 19(3), 775803. doi:10.1093/icc/dtq022

Athreye, S. S., \& Cantwell, J. A. (2005). Creating Competition? Globalisation and the Emergence of New Technology Producers. SSRN Electronic Journal. doi:10.2139/ssrn.824005

Atuahene-Gima, K. (1993). Buying Technology for Product Development in Smaller Firms. Industrial Marketing Management, 22(3), 223-232. doi:10.1016/0019-8501(93)90009-v

Benavente, J.M. (2006). The Role of Research and Innovation in Promoting Productivity in Chile. Economics of Innovation and New Technology, 15(4-5), 301-315. doi:10.1080/10438590500512794

Benavente, J.M. (2004). Innovación Tecnológica en Chile: ¿Dónde estamos y Qué se Puede Hacer? Central Bank Chile Working Papers, 295.

Benavente, J.M., de Mello, L., \& Mulder, N. (2005). Fostering Innovation in Chile. OECD Economics Department Working Papers. doi:10.1787/835465402444
Benavente, J. M., \& Lauterbach, R. (2008). Technological innovation and employment: complements or substitutes? The European Journal of Development Research, 20(2), 318-329. doi:10.1080/09578810802060744

Bravo-Ortega, C., Benavente, J. M., \& González, Á. (2014). Innovation, Exports, and Productivity: Learning and Self-Selection in Chile. Emerging Markets Finance and Trade, 50(s1), 68-95. doi:10.2753/ ree1540-496x5001s105

Canales, M. \& Álvarez, R., 2017. Impacto de los Obstáculos al Conocimiento en la Innovación de las Empresas Chilenas. Journal of Technology Management \& Innovation, 12 (3): 78-85. http://dx.doi. org/10.4067/S0718-27242017000300008

Chesbrough, H.W. (2003). Open innovation: the new imperative for creating and profiting from technology. Harvard Business School Press, Boston, Mass.

Corbo, V., \& Gonzalez, R. (2014). Growth opportunities for Chile, 1. ed. Ed. Universitaria,Santiago de Chile.

Crepon, B., Duguet, E., \& Mairesse, J. (1998). Research, Innovation, and Productivity: An Econometric Analysis at the Firm Level. National Bureau of Economic Research, doi:10.3386/w6696

Cruz, A., 2008. La Ruta de la Innovación en Chile. Journal of Technology Management \& Innovation, Vol. 3(1): 1-9.

De Gregorio, J. (2009). El crecimiento de Chile y el cobre. Banco Central de Chile.

De Leon, I., Fernandez Donoso, J. (2017). Sharing IP Strategy: Commercialization. Innovation, Startups and Intellectual Property Management, 45-60. https://doi.org/10.1007/978-3-319-549064_3

Fagerberg, J. (1994). Technology and International Differences in Growth Rates. Journal of Economic Literature, 32(3), 1147-1175. http://www.jstor.org/stable/2728605

Fernández-Arias, E. (2014). Productivity and Factor Accumulation in Latin America and the Caribbean: A Database. Washington, DC, United States: Research Department, Inter American Development Bank, https://publications.iadb.org/handle/11319/8402 (accessed 3.26.18).

Gambardella, A., Giuri, P., \& Luzzi, A. (2006). The Market for Patents in Europe. SSRN Electronic Journal. doi:10.2139/ssrn.899539

García-Manjón, J. V., \& Romero-Merino, M. E. (2012). Research, development, and firm growth. Empirical evidence from European top R\&D spending firms. Research Policy, 41(6), 1084-1092. doi:10.1016/j.respol.2012.03.017 
Granstrand, O., Patel, P., \& Pavitt, K. (1997). Multi-Technology Corporations: Why They Have "Distributed" Rather Than "Distinctive Core” Competencies. California Management Review, 39(4), 8-25. doi:10.2307/41165908

Griliches, Z. (1987). R\&D and Productivity: Measurement Issues and Econometric Results. Science, 237(4810), 31-35. doi:10.1126/science.237.4810.31

Hall, B.H., \& Rosenberg, N. (2010). Handbook of the economics of innovation. Vol. 1, 1. ed.,reprinted. ed, Handbooks in economics. North Holland, Amsterdam.

Japan Patent Office Annual Report (2004). Japan Patent Office.

Lei, D., \& Slocum, J. W. (1991). Global strategic alliances: Payoffs and pitfalls. Organizational Dynamics, 19(3), 44-62. doi:10.1016/00902616(91)90093-o

Lowe, J., \& Taylor, P. (1999). Imitation through technology licensing: strategic implications for smaller firms. International Journal of Innovation Management. 03(02), 185-207. https://doi.org/10.1142/ S1363919699000098

Maloney, W., \& Rodríguez-Clare, A. (2007). Innovation Shortfalls. Review of Development Economics, 11(4), 665-684. https://doi. org/10.1111/j.1467-9361.2007.00422.x

McKinsey \& Company, 2016. Automotive Revolution Perspective Towards 2030. How the Convergence of Disruptive TechnologyDriven Trends Could Transform the Auto Industry, Advanced Industries, January.

OECD, 2007. OECD Reviews of Innovation Policy: Chile. OECD, $\mathrm{Pa}$ ris. ISBN 978-92-64-03752-6. http://www.oecd.org/sti/inno/oecdreviewsofinnovationpolicychile.htm

OROPO, 2015. Who Owns the World's Patents? Why Patent Ownership Data Accuracy is a Problem Worth Solving?, http://oropo.net/ oropo_report_20150615.pdf

Parisi, M.L., Schiantarelli, F., \& Sembenelli, A. (2006). Productivity, innovation and R\&D: Microevidence for Italy. European Economic Review, 50(8), 2037-2061. https://doi.org/10.1016/j.euroecorev.2005.08.002
Pradhan, R.P., Arvin, M.B., Hall, J.H., \& Nair, M. (2016). Innovation, financial development and economic growth in Eurozone countries. Applied Economics Letters, 23(16), 1141-1144. https://doi.org/10.108 0/13504851.2016.1139668

Reyes, A., Ripamonti, M.T. (2008). Transferencia Tecnológica en Chile: Uso de patentes y Licenciamiento. Universidad de Chile, Chile.

Robbins, A. C., 2009. Measuring Payments for the Supply and Use of Intellectual Property. NBER Working Paper No. 11608. doi:10.7208/ chicago/9780226709604.003.0005

Romer, P.M. (1990). Endogenous technological change. Journal of Political Economy, 98(5), S71-S102. http://www.jstor.org/stable/2937632

Rouvinen, P. (2002). R\&D Productivity Dynamics: Causality, Lags, and "Dry Holes." Journal of Applied Economics, 5(1), 123-15.

Sheehan, J., Martínez, C., \& Guellec, D. (2004). Understanding Business Patenting and Licensing:Results of a Survey., in: Patents, Innovation and Economic Performance: OECD ConferenceProceedings. Organisation for Economic Co-operation and Development, Paris.

Shepard, A. (1987). Licensing to Enhance Demand for New Technologies. The RAND Journal of Economics, 18(3), 360. doi:10.2307/2555601

Solow, R. M. (1957). Technical Change and the Aggregate Production Function. The Review of Economics and Statistics, 39(3), 312. doi: $10.2307 / 1926047$

Teece, D. (1993). Profiting from technological innovation: Implications for integration, collaboration, licensing and public policy. Research Policy, 22(2), 112-113. doi:10.1016/0048-7333(93)90063-n

Wu, Y. (2011). Innovation and economic growth in China: evidence at the provincial level. Journal of the Asia Pacific Economy, 16(2), 129-142. https://doi.org/10.1080/13547860.2011.564752

Zuniga, M. P. and D. Guellec, 2009. Who Licenses Out Patents and Why? Lessons from a Business Survey. Statistical Analysis of Science, Technology and Industry STI Working Paper 2009/5.

Zuniga, P., \& Crespi, G. (2013). Innovation strategies and employment in Latin American firms. Structural Change and Economic Dynamics, 24, 1-17. doi:10.1016/j.strueco.2012.11.001 
